\title{
Genetic Diversity in Mimosa tenuiflora (Willd.) Poir.: A Multipurpose Plant Genetic Resource of Semiarid Brazil
}

\author{
Lorena S. Silva ${ }^{1}$, Renata R. Simplício ${ }^{1}$, Sendi R. Arruda ${ }^{1}$, Derval G. Pereira ${ }^{2}$, Milene Maria S. Castro ${ }^{1}$ \\ \& Ana Maria Waldschmidt ${ }^{1}$ \\ ${ }^{1}$ Department of Biological Sciences, Universidade Estadual do Sudoeste da Bahia, Jequié, Brazil \\ ${ }^{2}$ Department of Sciences and Technologies, Universidade Estadual do Sudoeste da Bahia, Jequié, Brazil \\ Correspondence: Lorena S. Silva, Program in Genetics, Biodiversity and Conservation, Department of \\ Biological Sciences, Universidade Estadual do Sudoeste da Bahia, 45205-490, Jequié, Brazil. Tel: \\ 55-(73)-98867-3805. E-mail: lorena.sdsc@gmail.com
}

Received: February 7, $2021 \quad$ Accepted: March 12, $2021 \quad$ Online Published: April 15, 2021

doi:10.5539/jas.v13n5p113 URL: https://doi.org/10.5539/jas.v13n5p113

The research is financed by Universidade Estadual do Sudoeste da Bahia (UESB) and Programa de Formação de Recursos Humanos/Petrobras (PRHPB211).

\begin{abstract}
Caatinga is the third largest biome in Brazil but little is known about the species diversity from this biotic community, despite of its social, economic and environmental importance for the semiarid region. Among the several typical plant species from Caatinga, Mimosa tenuiflora (Willd.) Poir. (black jurema) stands out because it plays a major role in the maintenance of this ecosystem, besides being widely used to recover degraded areas. Therefore, the goal of this study was to evaluate the genetic diversity and structural analysis from 10 populations of M. tenuiflora from the state of Bahia, northeastern Brazil, using 10 ISSR (Inter Simple Sequence Repeat) markers. A total of 117 fragments were obtained from 218 individuals with a mean number of 11.8 bands per primer. The mean population polymorphism was $85.0 \%$, while the values of genetic diversity $(\mathrm{He})$ and the Shannon index (I) were equal to 0.295 and 0.442 , respectively. Most of genetic variation was observed (87.0\%) but high $\mathrm{F}_{\mathrm{ST}}$ values were observed (0.132), indicating the populations are genetically differentiated. Bayesian inference using Structure divided the populations into two groups while Geneland indicated five clusters that could be related to the fragmentation of Caatinga and to constraints in the dispersal of pollen and seeds. In conclusion, M. tenuiflora presents high levels of genetic diversity and natural populations might serve as potential sources for management and reforestation of degraded areas in Caatinga.
\end{abstract}

Keywords: Caatinga, genetic diversity, ISSR, reforestation

\section{Introduction}

Caatinga is a poorly known and highly threatened biome, restricted to Brazilian semiarid areas that have suffered from intensive deforestation for cattle and charcoal production as well as inappropriate irrigation systems, thus leading to desertification, sedimentation of rivers and soil erosion (Leal et al., 2005). However, the lack of detailed information about the regional biodiversity restrains effective conservation efforts in Caatinga. Mimosa L. is a species-rich genus in Leguminosae, comprising about 540 taxa (Simon et al., 2011) widespread throughout distinct phytophysiognomies over tropical and subtropical regions in Americas. Brazil is a major center of origin for this genus (Barneby, 1991), with a high number of species (350), being 38 of them found in Caatinga (Queiroz, 2009; Dutra \& Morim, 2015a).

Mimosa tenuiflora (popularly known as black jurema) represents an important natural resource in Caatinga along semiarid regions of northeastern Brazil, being found in the states of Alagoas, Bahia, Ceará, Paraíba, Pernambuco, Piauí, Rio Grande do Norte and Sergipe (Dutra \& Morim, 2015b). Throughout its range, black jurema is widely used as timber for furniture, bridges, fences and studs, as charcoal in energy production (Maia, 2004; Riegelhaupt \& Pareyn, 2010) and to feed cattle (Braga, 1989). On the other hand, the tree bark powder is popular in traditional medicine to treat burns, acne, and wounds, since it presents antibiotic, analgesic and astringent properties (Albuquerque, 2007) and antifungal activity in the control of Alternaria alternata in citrus (Pinto et al., 
2018). Furthermore, it is considered a sacred plant for native tribes from semiarid Brazil who prepare a wine from the bark to be used as a ceremonial drink, a tradition that was later expanded to some Afro-Brazilian religious activities (Maia, 2004). As a matter of fact, psychoactive effects are recognized in jurema wine because it is rich in the alkaloid N, N-dimethyltryptamine or DMT (Souza, 2008). This specie has been regarded as "high conservation priority" after presenting local risk of extinction in the southern mesoregion of the state of Ceará because of overexploitation for medical purposes and animal feeding. The small number of individuals can be also related to losses of genetic variability contributing to lower population sizes (Santos et al., 2017).

Besides the social, cultural and economic relevance, black jurema also plays a major role in the maintenance of forest cover and ecological processes (e.g., pollinator attraction) in Caatinga favored by its fast growth and propagation, being particularly recommended to recover degraded areas (Queiroz, 2009; Maia-Silva et al., 2012). Adaptative morphological features to arid and semiarid ecosystems, such as higher size and stem diameter, make M. tenuiflora suitable for recovering degraded areas in Caatinga (Lima et al., 2018). This plant is visited by moths, butterflies, flies and beetles, but bees represent the main visitors since black jurema produces pollen throughout most of the year, being particularly helpful to the survival of colonies raised by bee keepers during dry seasons (Maia-Silva et al., 2012; Silva et al., 2015).

The knowledge about population structure is essential to conservation, genetic improvement, sustainable management, and selection of seed trees to recover deforested areas (Kageyama et al., 2003). The genetic diversity of M. tenuiflora was analyzed from 15 natural population located in state of Rio Grande Norte, revealing higher genetic variation within populations and the formation of four genetic groups. This study suggested that conservation efforts should focus on six populations, such as those with the highest and the lowest levels of genetic variation. In particular, the population of Espírito Santo (Rio Grande do Norte) was selected as a priority for conservation, as it presents the highest genetic distinctiveness in relation to the other population (Chagas, 2018). Hence, identification of genetically rich and divergent populations helps defining operational units that should be prioritized in ex situ or in situ conservation programs (Diniz-Filho \& Telles, 2002).

Forest fragmentation might eventually lead to decreased population effective size and high inbreeding levels, thus depleting the original genetic variation of natural populations that hence become more susceptible to environmental, demographic and genetic changes (Rajora \& Mosseller, 2001) even in widespread species such as M. tenuiflora. Several methods of molecular analyses have been used to assess the genetic diversity in natural populations of plants, including ISSR (Inter Simple Sequence Repeats) markers (Almeida et al., 2009). In spite of their dominant behavior, ISSR markers are advantageous to assess the genetic diversity in wild plants because they disregard previous information about genomes, are easily obtained, indicate variation within unique regions of the genome at several loci at the same time and provide reproducible results with high levels of polymorphism (Reddy et al., 2002; Kumar \& Yadav, 2018).

Therefore, the goal of this study was to evaluate the genetic diversity and population structure in M. tenuiflora along the state of Bahia, northeastern Brazil, based on ISSR markers. The present information is useful to the management and conservation of this species that represents a major plant resource in Caatinga.

\section{Material and Methods}

\subsection{Sampling}

Leaf samples from 218 individuals of $M$. tenuiflora were collected in 10 sites from the state of Bahia, which comprises the largest area within the natural range of this species, comprising about 564 thousand $\mathrm{km}^{2}$ (Table 1, Figure.1). To avoid the sampling of closely related individuals, a minimum distance of $10 \mathrm{~m}$ was applied among individual samples. A transect was defined across the state based on two major roads (BR-116 and BR-242) that cross the region and, thus, the sampling efforts comprised about $1,200 \mathrm{~km}$ from east to west and from north to south. Each sampled individual of M. tenuiflora was labeled in situ with a number code for identification and each sampled location was georeferenced using Garmin 12 GPS (Global Position System) receiver. The leaf samples were stored at $-20^{\circ} \mathrm{C}$ in the Laboratory of Molecular Genetics at UESB and voucher samples from each population were stored in the Herbarium from Universidade Estadual do Sudoeste da Bahia (HUESB) to confirm the species identification. The geographic distance among sampled populations was measured (Table 2) using the software DIVA-GIS (Hijmans et al., 2001) based on the coordinates of each collection site (Table 1). The coordinates were transformed into UTM (Universal Tranverse Mercator) values to calculate the distance among localities. 
Table 1. Localities, coordinates, altitude (A) and number of samples (N) per population of Mimosa tenuiflora (Willd.) Poir. in the state of Bahia

\begin{tabular}{lllll}
\hline Localities & Abbreviation & Coordinates & A (m) & N \\
\hline Vitória da Conquista & VC & $14^{\circ} 51^{\prime} 48^{\prime \prime} \mathrm{S} ; 40^{\circ} 50^{\prime} 48^{\prime \prime} \mathrm{W}$ & 874 & 24 \\
Poções & PO & $14^{\circ} 40^{\prime} 17^{\prime \prime} \mathrm{S} ; 40^{\circ} 18^{\prime} 42^{\prime \prime} \mathrm{W}$ & 911 & 20 \\
Jequié & $\mathrm{JE}$ & $13^{\circ} 49^{\prime} 18^{\prime \prime} \mathrm{S} ; 40^{\circ} 05^{\prime} 51^{\prime \prime} \mathrm{W}$ & 218 & 15 \\
Itaberaba & $\mathrm{IT}$ & $1^{\circ} 44^{\prime} 25^{\prime \prime} \mathrm{S} ; 40^{\circ} 19^{\prime} 53^{\prime \prime} \mathrm{W}$ & 272 & 21 \\
Seabra & $\mathrm{SE}$ & $1^{\circ} 24^{\prime} 58^{\prime \prime} \mathrm{S} ; 41^{\circ} 46^{\prime} 09^{\prime \prime} \mathrm{W}$ & 812 & 21 \\
Ibotirama & $\mathrm{IB}$ & $11^{\circ} 59^{\prime} 40^{\prime \prime} \mathrm{S} ; 43^{\circ} 12^{\prime} 50^{\prime \prime} \mathrm{W}$ & 115 & 25 \\
Barreiras & $\mathrm{BA}$ & $12^{\circ} 8^{\prime} 50^{\prime \prime} \mathrm{S} ; 44^{\circ} 59^{\prime} 40^{\prime \prime} \mathrm{W}$ & 454 & 21 \\
Santo Amaro & $\mathrm{SA}$ & $12^{\circ} 32^{\prime} 26^{\prime \prime} \mathrm{S} ; 38^{\circ} 42^{\prime} 39^{\prime \prime} \mathrm{W}$ & 8 & 20 \\
Serrinha & $\mathrm{SR}$ & $11^{\circ} 39^{\prime} 43^{\prime \prime} \mathrm{S} ; 39^{\circ} 00^{\prime} 32^{\prime \prime} \mathrm{W}$ & 379 & 25 \\
Euclides da Cunha & $\mathrm{1}$ & $1^{\circ} 30^{\prime} 29^{\prime \prime} \mathrm{S} ; 39^{\circ} 00^{\prime} 47^{\prime \prime} \mathrm{W}$ & 472 & 26 \\
Total & - & - & - & 218 \\
\hline
\end{tabular}

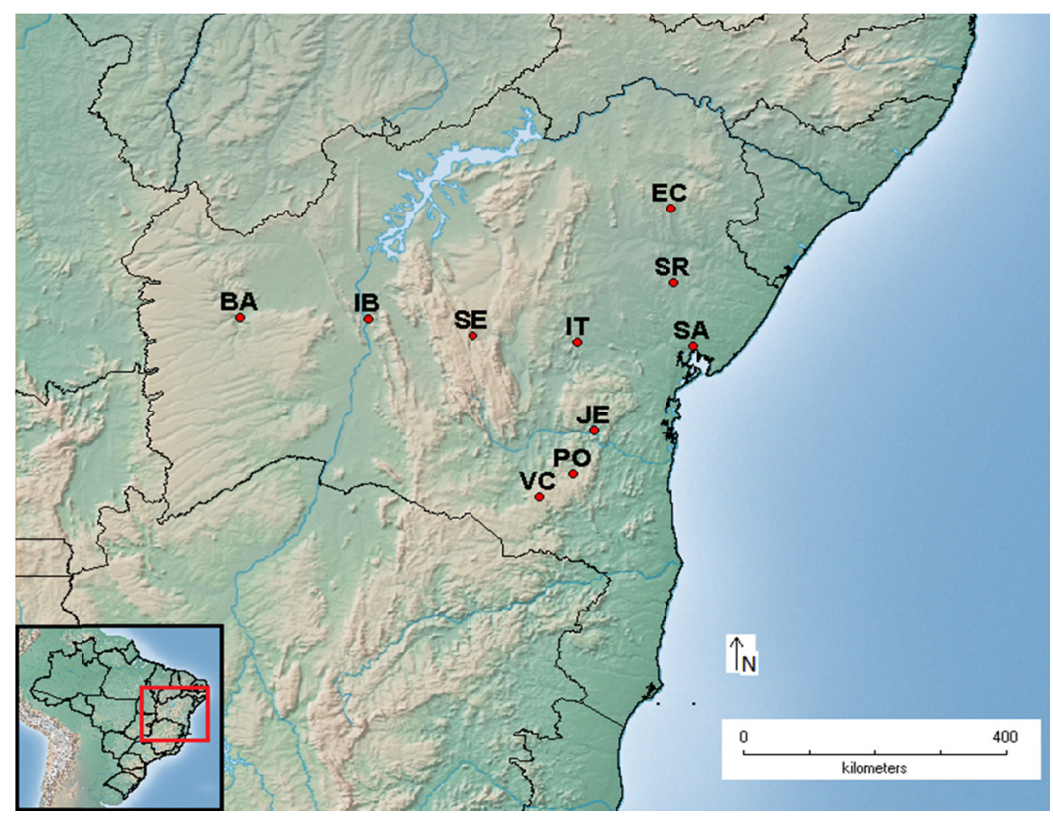

Figure 1. Mapping of the populations. Geographic distribution of the 10 sampled populations of Mimosa tenuiflora from the state of Bahia, Brazil (Table 1)

Table 2. Geographic distance among the populations of Mimosa tenuiflora collected in the state of Bahia, Brazil

\begin{tabular}{|c|c|c|c|c|c|c|c|c|c|c|}
\hline & $\mathrm{VC}$ & $\mathrm{PO}$ & $\mathrm{JE}$ & IT & $\mathrm{SE}$ & IB & $\mathrm{BA}$ & SA & SR & $\mathrm{EC}$ \\
\hline $\mathrm{VC}$ & 0 & & & & & & & & & \\
\hline PO & 63.0 & 0 & & & & & & & & \\
\hline JE & 143.0 & 97.0 & 0 & & & & & & & \\
\hline IT & 235.0 & 238.0 & 187.0 & 0 & & & & & & \\
\hline SE & 288.0 & 297.0 & 244.0 & 160.76 & 0 & & & & & \\
\hline IB & 412.0 & 433.0 & 401.0 & 322.01 & 166.0 & 0 & & & & \\
\hline BA & 542.0 & 582.0 & 568.0 & 510.2 & 353.0 & 196.0 & 0 & & & \\
\hline SA & 349.0 & 294.0 & 210.0 & 180.83 & 336.0 & 496.0 & 685.0 & 0 & & \\
\hline SR & 408.0 & 366.0 & 274.0 & 188.31 & 313.0 & 456.0 & 656.0 & 107.0 & 0 & \\
\hline EC & 523.0 & 484.0 & 391.0 & 285.74 & 371.0 & 487.0 & 680.0 & 232.0 & 130.0 & 0 \\
\hline
\end{tabular}

\subsection{DNA Extraction and Amplification}

The total DNA was isolated from leaves of M. tenuiflora according to the optimized protocol by Arruda et al. (2017). After isolation, the DNA samples were quantified in $0.8 \%$ agarose gel using L-Quant spectrophotometer 
(Loccus). Forty ISSR primers provided by UBC (University of British Columbia) were tested and 10 of them were selected based on their repeatability and high-quality of band profiles (Table 3).

Table 3. ISSR primers and their respective sequences, annealing temperature (Tm), total number of loci, and number of polymorphic loci

\begin{tabular}{lllll}
\hline Primer & Sequence $\left(5^{\prime}-3^{\prime}\right)$ & $\operatorname{Tm}\left({ }^{\circ} \mathrm{C}\right)$ & Number of loci & Number of polymorphic loci \\
\hline UBC-807 & AGAGAGAGAGAGAGT & 53 & 10 & 8 \\
UBC-811 & GAGAGAGAGAGAGAGAC & 53 & 11 & 9 \\
UBC-812 & GAGAGAGAGAGAGAGAA & 52 & 10 & 9 \\
UBC-815 & CTCTCTCTCTCTCTCTG & 55 & 14 & 12 \\
UBC-827 & ACACACACACACACACG & 53 & 16 & 14 \\
UBC-836 & AGAGAGAGAGAGAGAGYA & 52 & 10 & 5 \\
UBC-845 & CTCTCTCTCTCTCTCTRG & 53 & 11 & 10 \\
UBC-854 & CTCTCTCTCTCTCTCRG & 54 & 16 & 15 \\
UBC-856 & ACACACACACACACACYA & 53 & 12 & 10 \\
UBC-864 & ATGATGATGATGATGATG & 53 & 7 & 7 \\
Total & - & - & 117 & 99 \\
Mean & - & - & 11.8 & 9.9 \\
\hline
\end{tabular}

The DNA amplification via PCR (Polymerase Chain Reaction) was performed using $10 \mathrm{mM}$ Tris-HCl $\mathrm{pH} 8.3$, $2.5 \mathrm{mM}$ of $\mathrm{MgCl}_{2}, 1 \mathrm{mM}$ of dNTPs, $0.2 \mathrm{M}$ of each primer, $5 \mathrm{U}$ of Taq DNA polymerase (Biotools) and $40 \mathrm{ng}$ of template DNA and ultrapure water to a final volume of $25 \mu \mathrm{L}$ in a MG108+ thermocycler. The PCR conditions were: first denaturation step at $94{ }^{\circ} \mathrm{C}$ for $3 \mathrm{~min}$, followed by 40 cycles of $1 \mathrm{~min}$ at $92{ }^{\circ} \mathrm{C}, 2 \mathrm{~min}$ at optimum annealing temperature (Table 3), 2 min at $72{ }^{\circ} \mathrm{C}$, plus a final extension at $72{ }^{\circ} \mathrm{C}$ for $7 \mathrm{~min}$. The amplified products were run in $1.2 \%$ agarose gel for $2 \mathrm{~h}$ and $30 \mathrm{~min}$ at 100 volts and photodocumented under UV light using L-Pix system (Loccus). A 1000-bp ladder was used to estimate the fragment size while poorly define or weakly stained bands were disregarded from the present analyses.

\subsection{Data Analysis}

A binary matrix from the band profile for each ISSR primer was built in which " 0 " and " 1 " indicated the absence and the presence of a particular band, respectively. Based on these data, we estimated the Shannon's (I) and Nei's (He) genetic diversity (Nei, 1973), Nei's genetic distance (Nei, 1978), gene differentiation between populations $\left(\mathrm{F}_{\mathrm{ST}}\right)$ and gene flow $(\mathrm{Nm})$ levels using the software TFPGA 1.3 (Miller, 1997). The pairwise Nei's genetic distances was estimated using the software GenAlEx 6.5. In order to verify whether the genetic and geographic distances were correlated or not, we performed the Mantel's test (Manly, 1997) with 10,000 permutations, using AIS 1.0 (Miller, 2005). In the software Arlequin 3.0 (Excoffier \& Schneider, 2005), we carried out the analysis of molecular variance (AMOVA) to estimate how the genetic variation was partitioned using 10,000 bootstrap permutations to test its significance.

To estimate the degree of admixture among sampled populations, a Bayesian inference of population structure was obtained in the software STRUCTURE 2.2.3 (Falush et al., 2007). The number of tested populations (K) ranged from 1 to 11, with 10 iterations and 1 million MCMC (Markov Chain Monte Carlo) generations with a burn-in of 100,000 generations. After adjustments in the software for dominant markers, we determined the best admixture model and assumed that the allele frequencies were uncorrelated among populations (Wang et al., 2012). The most likely K value was calculated using the platform Structure Harvester Web v.0.6.9 following the parameters established by Evanno et al. (2005). A second Bayesian model was tested using the GENELAND R package in order to analyze the geographic distribution of the genetic variation (Guillot, 2012). The number of clusters $(\mathrm{K})$ was defined within an interval from 1 to 10 to infer the actual $\mathrm{K}$ value comprising the maximum number of populations following 1 million MCMC generations and a burn-in of 1,000 generations. A Principal Component Analysis (PCA) was also performed using the software PAST (Hammer et al., 2001) to visualize the degree of relatedness between populations based on the matrix of genetic distance for the 117 ISSR alleles.

\section{Results}

\subsection{Genetic Diversity}

A total of 117 bands were obtained from the 218 individuals of $M$. tenuiflora. The number of amplicons per ISSR primer ranged from 7 to 16 (UBC-864 and UBC-827, respectively), with a mean number of 11.8 bands/primer 
(Table 3) and fragment sizes between 250 and 2000 base pairs (pb). At a population level, the mean percentage of polymorphic bands per locality was $85.0 \%$, being the lowest and the highest values observed in Jequié (65.0\%) and Serrinha (94.9\%), respectively (Table 4). The mean values of genetic diversity for the 10 populations were estimated in 0.295 (He) and 0.442 (I). On the other hand, these values were highly differentiated among populations, ranging from $\mathrm{He}=0.239$ and $\mathrm{I}=0.354$ in Jequié $(\mathrm{JE})$ to $\mathrm{He}=0.369$ and $\mathrm{I}=0.538$ in Serrinha $(\mathrm{SR})$ (Table 4).

Table 4. Nei's genetic diversity (He), Shannon's index (I) and percentage of polymorphic loci (PLP) in populations of Mimosa tenuiflora from the state of Bahia, Brazil

\begin{tabular}{llll}
\hline Population & $\mathrm{He}$ & $I$ & PLP $(\%)$ \\
\hline VC & 0.299 & 0.443 & 82.0 \\
PO & 0.315 & 0.466 & 84.6 \\
JE & 0.239 & 0.354 & 65.0 \\
IT & 0.339 & 0.496 & 88.0 \\
SE & 0.347 & 0.509 & 91.4 \\
IB & 0.348 & 0.510 & 90.6 \\
BA & 0.294 & 0.434 & 79.5 \\
SA & 0.305 & 0.450 & 81.2 \\
SR & 0.369 & 0.538 & 94.9 \\
EC & 0.368 & 0.536 & 94.0 \\
Mean & 0.322 & 0.474 & 85.0 \\
\hline
\end{tabular}

\subsection{Genetic Structure in Natural Populations of Mimosa tenuiflora}

The AMOVA revealed that most of genetic variation was found within populations (87.0\%) of M. tenuiflora (Table 5). Nonetheless, high and significant levels of interpopulation genetic differentiation were detected $\left(\mathrm{F}_{\mathrm{ST}}=\right.$ $0.132 ; \mathrm{p}=0.001)$ along with estimates of less than one migrant individual per generation $(\mathrm{Nm}=0.87 ; \mathrm{p}<0.001)$. In fact, Mantel's test revealed significant correlation between genetic and geographic distances in the analyzed populations $(\mathrm{r}=0.19, \mathrm{p}=0.001)$. The lowest values in pairwise genetic distance were observed between the samples from $\mathrm{VC} \times \mathrm{PO}(0.074)$ and $\mathrm{PO} \times \mathrm{JE}(0.087)$, while the populations from $\mathrm{VC}$ and $\mathrm{EC}$ showed the highest genetic divergence $(0.225)$ (Table 6$)$.

Table 5. Population structure and genetic divergence in populations of Mimosa tenuiflora from the state of Bahia based on 10 ISSR markers

\begin{tabular}{llllll}
\hline Source of variation & AMOVA $^{\mathrm{a}}(\%)$ & $p$-value & $\mathrm{F}_{\mathrm{ST}}{ }^{\mathrm{b}}$ & $p$-value* & $\mathrm{Nm}^{\mathrm{c}}$ \\
\hline Among populations & 13.0 & $<0.000$ & 0.132 & $<0.001$ & 0.870 \\
Within populations & 87.0 & $<0.000$ & & & \\
Total & 100 & & & & \\
\hline
\end{tabular}

Note. ${ }^{\mathrm{a}}=$ analyses of molecular variance; ${ }^{\mathrm{b}}=$ index of genetic fixation; ${ }^{\mathrm{c}}=$ gene flow; ${ }^{*}$ significance level.

Table 6. Pairwise Nei’s genetic distance in populations of Mimosa tenuiflora from the state of Bahia, Brazil

\begin{tabular}{lllllllllll}
\hline & VC & PO & JE & IT & SE & IB & BA & SA & SR & EC \\
\hline VC & 0.000 & & & & & & & & & \\
PO & 0.074 & 0.000 & & & & & & & & \\
JE & 0.192 & 0.087 & 0.000 & & & & & & & \\
IT & 0.182 & 0.134 & 0.098 & 0.000 & & & & & & \\
SE & 0.178 & 0.135 & 0.140 & 0.134 & 0.000 & & & & \\
IB & 0.148 & 0.122 & 0.104 & 0.088 & 0.123 & 0.000 & & & \\
BA & 0.200 & 0.165 & 0.147 & 0.149 & 0.175 & 0.151 & 0.000 & & & \\
SA & 0.207 & 0.150 & 0.167 & 0.166 & 0.161 & 0.164 & 0.138 & 0.000 & & \\
SR & 0.216 & 0.171 & 0.154 & 0.119 & 0.171 & 0.139 & 0.220 & 0.158 & 0.000 & 0.165 \\
EC & 0.225 & 0.218 & 0.215 & 0.180 & 0.167 & 0.210 & 0.199 & 0.193 & 0.160 \\
\hline
\end{tabular}


Accordingly, the Bayesian inference of population structure confirmed that the $\mathrm{K}=2$ is the most suitable number of genetic groups in M. tenuiflora (Figure 2) (see Appendix A1 for details). The first group (green) comprised the populations VC, BA, SA and EC and the second (red) grouped the populations PO, JE, IT, SE, IB and SR. The analysis based on GENELAND separated the 10 populations into five clusters (Figure 3). The first cluster (dark green) was formed by samples from BA; the second group (light green) comprised the VC and PO populations; the third group (yellow) encompassed the SA and SR samples; the fourth group (beige) was formed by EC; and the fifth group (grey) grouped the samples from IB, SE, IT and JE. Moreover, the PCA discriminated only the population from BA in relation to the others, which composed a large group (Figure 4).

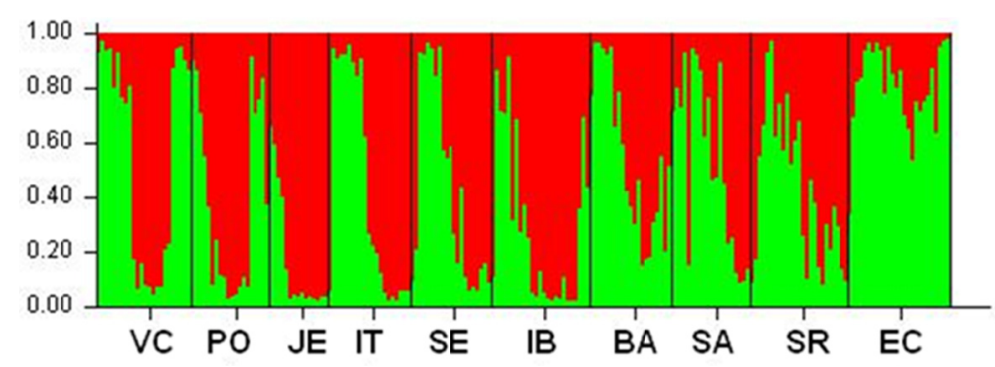

Figure 2. Result of population analysis of Mimosa tenuiflora showing the genetic relatedness of 10 populations of Mimosa tenuiflora (Table 1) estimated by STRUCTURE based on ISSR markers $(\mathrm{K}=2$; Mean $(\mathrm{LnProb})=$ -14143.590). The vertical lines indicate the specimens and the colors represent the allele frequencies

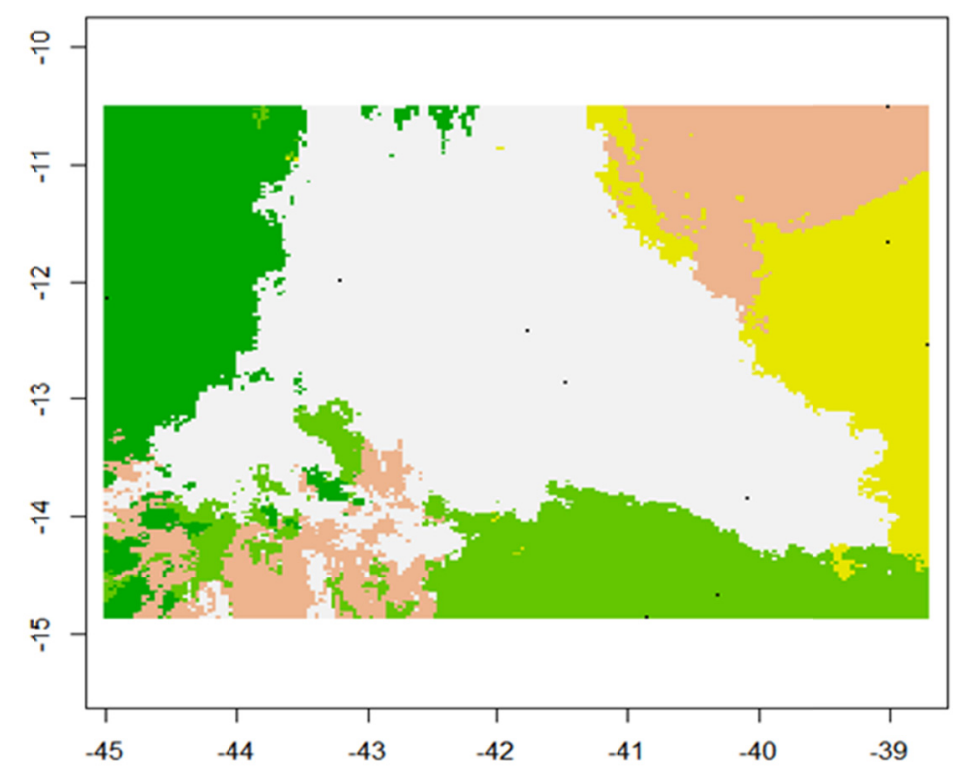

Figure 3. Mosaic of the spatial distribution of genetic groups in Mimosa tenuiflora based on the algorithm implemented in GENELAND $(\mathrm{K}=5)$. The dots indicated the geographic location of populations and each color represents the genetic clusters, as follows: 1 (light green) comprising the BA samples, 2 (dark green) encompassing VC and PO, 3 (yellow) including SA and SR, 4 (beige) composed of EC and 5 (grey) comprising JE, IT, SE and IB 


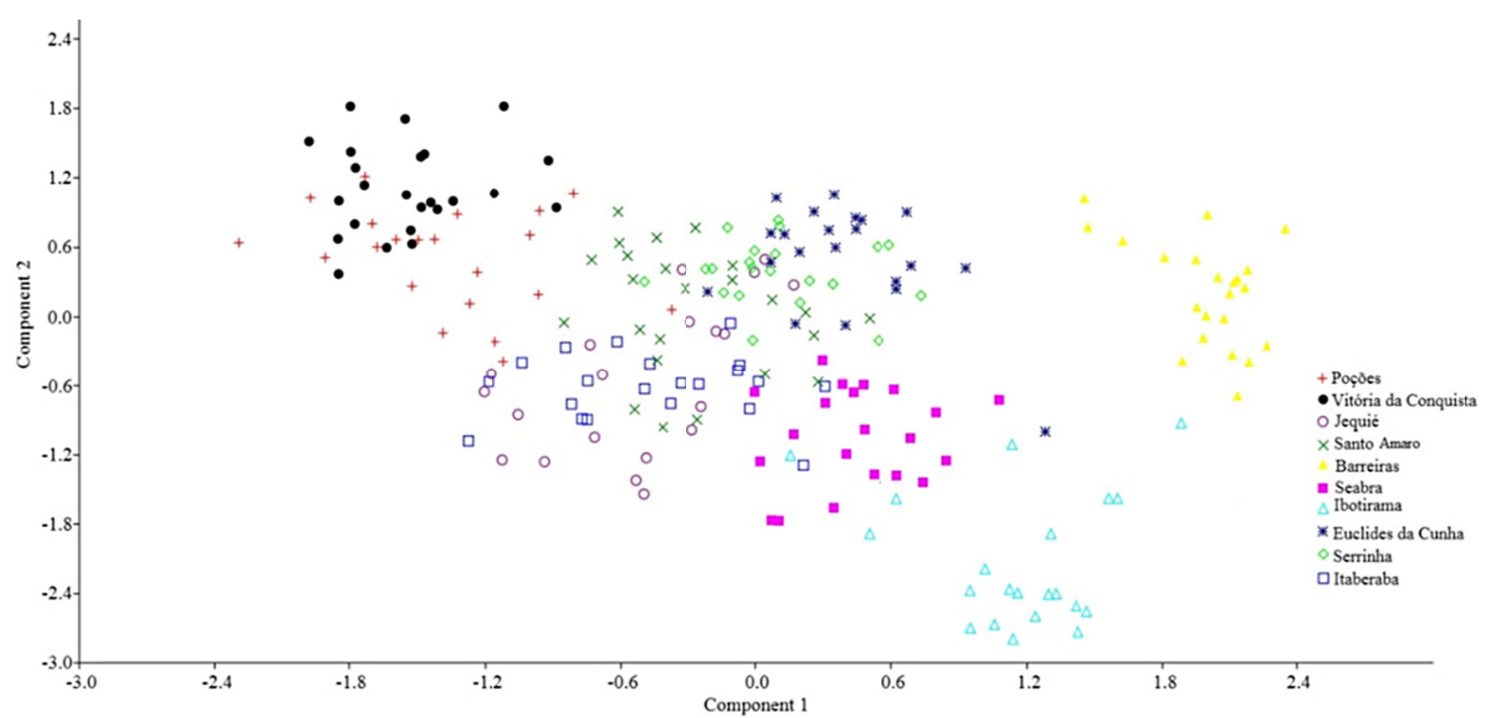

Figure 4. Graph of the PCA showing the position of each population along the axis. Principal Component Analysis (PCA) in populations Mimosa tenuiflora sampled in the state of Bahia, Brazil, based on the matrix of genetic distance of 117 ISSR alleles

\section{Discussion}

\subsection{Genetic Diversity}

A high percentage of polymorphic loci (mean value around $85.0 \%$ ) was detected in the present study, being superior to that reported in M. tenuiflora (65.3\%) (Chagas, 2018) and Mimosa caesalpiniaefolia Benth (52.7\%) (Araújo et al., 2016). The present values are typical of cross-fertilized plants as commonly observed in Fabaceae species, like Enterolobium contortisiliquum (Moreira et al., 2015) and Erythrina velutina Willd (Gonçalves et al., 2014). Increased levels of polymorphism have also been described in plant species from heterogeneous desert habitats, such as Medicago ruthenica (L.) Trautv. (Fabaceae) (Li et al., 2013), Haloxylon ammodendron (Sheng et al., 2004) and H. salicornicum moq (Amaranthaceae) (Salameen et al., 2018). Similarly, Caatinga is a semiarid biome characterized by habitats with differences in sunlight incidence, mean temperatures, rates of evapotranspiration, and rainfall, usually restricted to short seasonal periods (Leal et al., 2003). As a result, species living in differentiated habitats under stressful conditions usually present high values of genetic variation across their range related to local adaptation processes (Martínez-Palacios et al., 1999; Shrestha et al., 2002). The lowest polymorphism observed in the populations from $\mathrm{JE}(65.0 \%)$ is likely to reflect the high degree of deforestation for agriculture and timber exploitation in this area, determining population decline and high levels of inbreeding eventually reducing local genetic variation.

The Nei's genetic distance and Shannon index values in M. tenuiflora were similar to those observed in other leguminous plants (Fabaceae), such as M. ruthenica (Li et al., 2013) and Adesmia bijuga (Guerra et al., 2018). According to Cole (2003), non-rare plant species usually show increased genetic diversity, since genetic drift is affected by small populations, resulting in decreased heterozygosity levels. This statement corroborates the present study since $M$. tenuiflora is an abundant species with high levels of genetic polymorphism. It should be pointed out that the genetic diversity is a key feature to the evolutionary potential of species inasmuch as it allows selecting adaptive genotypic combinations to specific environmental conditions (Sebbenn et al., 2000; Freeland et al., 2011).

\subsection{Genetic Structure and Gene Flow}

The present data revealed low levels of gene flow among populations of $M$. tenuiflora $(\mathrm{Nm}=0.87)$ and moderate population genetic structure $\left(\mathrm{F}_{\mathrm{ST}} \sim 0.13 ; \mathrm{p}=0.001\right)$. In plants, $\mathrm{F}_{\mathrm{ST}}$ values above 0.15 are regarded as evidence of high population structure (Frankham et al., 2002), being inversely proportional to gene flow levels (Salameen et al., 2018). Most of genetic variation in M. tenuiflora was found within populations, as similarly observed in a previous report with this species in state of Rio Grande do Norte (Chagas, 2018) and other cross-fertilized plants such as M. ruthenica (Li et al., 2013), Caryocar brasiliense camb. (Melo Jr. et al., 2012), H. ammodendron (Sheng et al., 2004), and H. salicornicum (Salameen et al., 2018). Nonetheless, the reproductive biology of $M$. 
tenuiflora, an essential aspect to infer the population genetic structure (Hamrick, 1989; Salameen et al., 2018), remains largely unknown.

As observed in other biomes, Caatinga has been impacted by human activities (e.g., uncontrolled deforestation) thus leading to habitat fragmentation which restrains the gene flow among the populations of M. tenuiflora. Previous reports suggest that values of gene flow equal or higher than 1.0 are able to prevent the genetic differentiation among populations (Slatkin \& Barton, 1989). According to the present cluster analyses and Nm values, the gene flow among the samples of $M$. tenuiflora are insufficient to avoid the population structure, putatively favored by the effects of low connectivity among individuals from fragmented habitats. Nonetheless, other features such as genetic isolation by geographic distance and genetic drift should also be taken into account (Khierallah et al., 2014). M. tenuiflora usually occur in aggregates with high population density, besides presenting reduced life cycles ( $\sim 20$ years) and short-distance seed dispersal, being thus more susceptible to limited gene flow and high genetic population structure (Wright, 1943).

The groups formed evidenced by the cluster analysis (Figure 2 and Figure 4) may result from the increased gene flow among nearby individuals along the distribution of populations, following the isolation-by-distance model by Wright (1943). Considering the high fragmentation of the Caatinga biome, gene flow can also be limited by the pollination by insects that usually fly over short distances. To date, there are no studies about the pollen dispersal in M. tenuiflora, but bees, wasps and flies have been regarded as their main pollinators (Maia-Silva et al., 2012). For instance, bees (Apis mellifera and Bombus morio) have been observed as effective pollinators of M. bimucronata (Silva et al., 2011) while domestic goats (Capra hircus) have been reported as occasional dispersers of $M$. luisana, because the infestation of bruchids in seeds can reduce the amount of seeds in the excrement from goats (Giordani, 2008). The Mantel's test corroborated the isolation model since a low but significant correlation between genetic and geographic distance was observed $(r=0.19, p<0.001)$.

The number of clusters differed between both Bayesian approaches, what could be related to the distinct parameters from each analysis. It should be pointed out that Geneland takes into consideration the geographic and genetic values while Strucutre considers only the genetic estimates. According to the results based on Geneland, the cluster 1 included the first record of M. tenuiflora in cerrado (a Brazilian savannah biome), represented by the samples from BA. The discrimination of BA individuals in two out of the three cluster analyses should be related to the fact that this is the only population of this species found in cerrado and separated by the São Francisco River (Figure 1), thus placing this locality apart from all the other populations and putatively acting as a barrier to gene flow. The group 2 (VC and PO) comprised the populations separated by short geographic distances, high altitude and similar vegetation, favoring gene flow within this cluster. Similarly, the populations in group 3 (SA and SR) represented nearby localities in the northern portion of Bahia. The group 4 (EC) was separated from the others, representing the population located in the northern range of this species. The populations from the group 5 (IT, SE, IB, and JE) are geographically close to each other and inhabit areas that share similar altitudes, landscape and rainfall indexes (Tables 1 and 2). A similar separation of clusters was observed in the analysis using Structure, inasmuch four (IT, SE, IB and JE) out of six populations in group 2 (IT, $\mathrm{SE}, \mathrm{IB}, \mathrm{JE}, \mathrm{PO}$ and SR) were clustered in both Bayesian approaches.

Once the genetic diversity is directly related to the survival of species in face of environmental changes (Freeland et al., 2011) and little is known about the genetic structure in most organisms from dry regions, the present data in populations of $M$. tenuiflora from semiarid regions are essential to the proper restoration of forest cover in degraded biomes, such as Caatinga. The use of pioneer plants such as M. tenuiflora enables the subsequent establishment of other species, the stabilization and increase of the biological activity of the soil (Chaves et al., 2006), thus being a key species to maintaining biodiversity and ecosystem functionality. In general, the populations presented high levels of genetic variation, being relevant to species conservation. Moderate population structure in black jurema is possibly related to the remarkable fragmentation of Caatinga and biological features of the analyzed species that favor the genetic differentiation among populations of $M$. tenuiflora across their range. Therefore, the local conservation of genetically divergent populations is strongly recommended. In particular, special attention should be drawn to those populations with the highest levels of polymorphism to be used in reforestation programs in Caatinga or as sources for ex situ and in situ conservation of M. tenuiflora.

Then, we indicate the SR, EC and IB populations was the best options to management and conservation plans inasmuch as they present high rates of genetic diversity, therefore, being the most genetically represented populations. We also point out the importance of conserving the populations from JE, BA and SA since they share low levels of genetic variation in order to avoid furthers genetic losses. 


\section{Acknowledgements}

The authors gratefully acknowledge the financial support of Universidade Estadual do Sudoeste da Bahia (UESB), Programa de Formação de Recursos Humanos/Petrobras (PRHPB211) and Coordenação de Aperfeiçoamento de Pessoal de Nível Superior-Brazil (CAPES)-Finance Code 001.

\section{References}

Albuquerque, U. P., Medeiros, P. M., Almeida, A. L. S., Monteiro, J. M., Lins-Neto, E. M. F., Melo, J. G., \& Santos, J. P. (2007). Medicinal plants of the Caatinga (semi-arid) vegetation of NE Brazil: A quantitative approach. J. Ethnopharmacol, 114(3), 325-54. https://doi.org/10.1016/j.jep.2007.08.017

Almeida, C. M. A., Lima, S. E. N., Lima, G. S. A., Brito, J. Z., Sabino, V. M. T., \& Silva, M. V. (2009). Caracterização Molecular de Cultivares de Cana-de-açúcar Utilizando Marcadores ISSR. Ciência e Agrotec. 33(SP), 1771-1776. https://doi.org/10.1590/S1413-70542009000700012

Araújo, F. S., Pacheco, M. V., Vieira, F. A., Ferrari, C. S., Félix, F. C., \& Chagas, K. P. T. (2016). ISSR molecular markers for the study of the genetic diversity of Mimosa caesalpiniaefolia Benth. Idesia, 34(3), 45-50. https://doi.org/10.4067/S0718-34292016000300007

Arruda, S. R., Pereira, D. G., Silva-Castro, M. M., Brito, M. G., \& Waldschmidt, A. M. (2017). An optimized protocol for DNA extraction in plants with a high content of secondary metabolites, based on leaves of Mimosa tenuiflora (Willd.) Poir. (Leguminosae). Genet Mol Res, 16(3). https://doi.org/10.4238/gmr160 39063

Barneby, C. R. (1991). Sensitivae Censitae. A description of the genus Mimosa L. (Mimosaceae) in the New World. Mem N Y Bot Gard., 65, 835.

Braga, R. (1989). Plantas do Nordeste, especialmente no Ceará. Editora Universitária da UFRN, Natal, Rio Grande do Norte.

Chagas, K. P. T. (2018). Diversidade genética e modelagem preditiva de distribuição de Mimosa tenuiflora (Willd) Poiret (Master's thesis, Universidade Federal do Rio Grande do Norte, Macaíba, Brazil). Retrieved from https://repositorio.ufrn.br/bitstream/123456789/26582/1/Diversidadegen\%C3\%A9ticamodelagem_Chagas_ 2018.pdf

Chaves, L. L. B. (2006). Crescimento de mudas de angico-vermelho em substrato fertilizado e inoculado com rizóbio. Revista Árvore, 30, 911-919. https://doi.org/10.1590/S0100-67622006000600006

Cole, C. T. (2003). Genetic variation in rare and common plants. Annu Rev Ecol Evol Syst, 34(1), $213-237$. https://doi.org/10.1146/annurev.ecolsys.34.030102.151717

Diniz-Filho, J. A. F., \& Telles, M. P. C. (2002). Spacial autocorrelation analysis and the identification of operational units for conservation in continuous populations. Conserv Biol, 16(4), 924-935. https://doi.org/ 10.1046/j.1523-1739.2002.00295.x

Dutra, V. F., \& Morim, M. P. (2015a). Mimosa in Lista de Espécies da Flora do Brasil. Jardim Botânico do Rio de Janeiro. Retrieved from http://floradobrasil.jbrj.gov.br/jabot/floradobrasil/FB18831

Dutra, V. F., \& Morim, M. P. (2015b). Mimosa in Lista de Espécies da Flora do Brasil. Jardim Botânico do Rio de Janeiro. Retrieved from http://floradobrasil.jbrj.gov.br/jabot/fichapublicataxonuc/fichapublicataxonuc. do? $\mathrm{id}=\mathrm{fb} 18874$

Evanno, G., Regnaut, S., \& Goudet, J. (2005). Detecting the number of clusters of individuals using the software STRUCTURE: A simulation study. Mol Ecol, 14(8), 2611-20. https://doi.org/10.1111/j.1365-294X.2005. 02553.x

Excoffier, L. G., \& Schneider, S. (2005). Arlequin, version 3.1 for Windows: An integrated software package for population genetics data analysis. Evol Bioinform Online, 1, 47-50. https://doi.org/10.1177/11769343 0500100003

Falush, D., Stephens, M., \& Prichard, J. K. (2007). Inference of population structure using multilocus genotype data: Dominant markes and null alleles. Mol Ecol, 7(4), 574-578. https://doi.org/10.1111/j.1471-8286. 2007.01758.x

Frankham, R., Briscoe, D. A., \& Ballou, J. D. (2002). Introduction to conservation genetics. Cambridge University Press. https://doi.org/10.1017/CBO9780511808999 
Freeland, J. R., Kirk, H., \& Petersen, S. (2011). Molecular ecology. Chichester, West Sussex. https://doi.org/ $10.1002 / 9780470979365$

Giordani, L. (2008). The role of goats in germination and dispersal of Mimosa luisana Brandegee (Leguminosae-Mimosoideae) seeds in Tehuacán-Cuicatlán Valley, Puebla State, Mexico (Master's thesis, Norwegian University of life Sciences, Oslo, Norway). Retrieved from https://www.researchgate.net/ publication/242144285

Gonçalves, L. O., Pinheiro, J. B., Zucchi, M. I., \& Silva, R. (2014). Caracterização genética de mulungu (Erythrina velutina Willd.) em áreas de baixa ocorrência. Ciênc. Agron., 45, 290-298. https://doi.org/ 10.1590/S1806-66902014000200009

Guerra, F. P., Gomez, P., Gutierrez, A., \& Hahn, S. (2018). Genetic diversity of Adesmia bijuga Phil., an endangered Fabaceae species from Central Chile. Braz. J. Bot., 41, 247-251. https://oi.org/10.1007/ s40415-018-0440-5

Guillot, G., Mortier, F., \& Estoup, A. (2005). GENELAND: A computer package for landscape genetics. Molecular Ecology Notes, 5, 712-715. https://doi.org/10.1111/j.1471-8286.2005.01031.x

Hammer, O., Harper, D. A. T., \& Ryan, P. D. (2001). PAST, version 2.0 for Windows: Palaeontological Statistics software package for education and data analysis. Palaeontol. Electron., 4, 1-9.

Hamrick, J. L. (1989). Isozymes and the analysis of genetic structure in plant. In J. L. Hamrick (Ed.), Isozymes in plant biology (pp. 87-105). Springer, Dordrecht. https://doi.org/10.1007/978-94-009-1840-5_5

Hijmans, R. J., Guarino, L., Cruz, M., \& Rojas, E. (2001). Computer tools for spatial analysis of plant genetic resources data: 1. DIVA-GIS. Plant Genetic Resources Newsletter, 127, 15-19.

Kageyama, P. Y., Gandara, F. B., \& Oliveira, R. E. (2003). Biodiversidade e restauração da floresta tropical. In P. Y. Kageyama, F. B. Gandara, R. E. Oliveira, L. F. D. Moraes, V. L. Engel, \& F. B. Gandara (Eds.), Restauração ecológica de ecossistemas naturais (pp. 27-48). Botucatu, São Paulo.

Khierallah, H. S. M., Al-Sammarraie, S. K. I., \& Mohammed, H. I. (2014). Molecular characterization of some Iraqi date palm cultivars using RAPD and ISSR markers. J of Asian Sci Res, 4, 490-503.

Kumar, V., \& Yadav, H. K. (2018). Assessment of genetic diversity in Lepidium sativum L. using inter simple sequence repeat (ISSR) marker. Physiol Mol Biol Plants, 25(2), 399-406. https://doi.org/10.1007/s12298018-0622-4

Leal, I. R., Silva, J. M. C., Tabarelli, M., Thomas, E., \& Lacher, J. R. (2005). Mudando o curso da conservação da biodiversidade na Caatinga do Nordeste do Brasil. Megadiversidade, 1, 139-146.

Leal, I. R., Tabarelli, M., \& Silva, J. M. C. (2003). Ecologia e conservação da Caatinga. Ed Universitária da UFPE, Recife.

Li, H., Li, Z., Cai, L., Shi, W., Mi, F., \& Shi, F. (2013). Analysis of genetic diversity of Ruthenia Medic (Medicago ruthenica (L.) Trautv.) in Inner Mongolia using ISSR and SSR markers. Genet Resour Crop Evol, 60, 1687-1694. https://doi.org/10.1007/s10722-012-9950-3

Lima, A. T., \& Meiado, M. V. (2018). Effect of hydration and dehydration cycles on Mimosa tenuiflora seeds during germination and initial development. South African Journal of Botany, 116, 164-167. https://doi.org/ 10.1016/j.sajb.2018.03.017

Maia, G. N. (2004). Caatinga: Árvores e arbustos e suas utilidades. D\&Z Computação Gráfica e Editora, São Paulo.

Maia-Silva, C., Silva, C. I., Hrncir, M., Queiroz, R. T., \& Imperatriz-Fonseca, V. L (2012). Guia de plantas visitadas por abelhas na Caatinga. Fundação Brasil Cidadão, Fortaleza.

Manly, B. J. F. (1997). Randomization, Bootstrap and Monte Carlo Methods in Biology. Chapman \& Hall, London.

Martínez-Palacios, M., Eguiarte, L. E., \& Furnier, G. R. (1999). Genetic Diversity of the Endangered Endemic Agave Victoriae reginae (Gavaceae) in the Chihuahuan Desert. Am J Bot, 86(8), 1093-8. https://doi.org/ $10.2307 / 2656971$

Melo Jr., A. F., Carvalho, D., Vieira. F. A., \& Oliveira. D. A. (2012). Spatial genetic structure in natural populations of Caryocar brasiliense Camb. (Caryocaraceae) in the North of Minas Gerais, Brazil. Biochem Syst Ecol, 43, 205-209. https://doi.org/10.1016/j.bse.2012.02.005 
Miller, P. M. (1997). TFPGA: Tools for populations genetics analyses. IOP Publishing Physics. Retrieved from http://www.ccg.unam.mx/ vinuesa/tlem09/docs/TFPGADOC.PDF

Miller, P. M. (2005). Alleles In Space (AIS): Computer Software for the Joint Analysis of Interindividual Spatial and Genetic Information. The Journal of Heredity, 96(6), 722-4. https://doi.org/10.1093/jhered/esi1 19

Moreira, P. de A., Brandão, M. M., de Araujo, N. H., de Oliveira, D. A., \& Fernandes, G. W. (2015). Genetic diversity and structure of the tree Enterolobium contortisiliquum (Fabaceae) associated with remnants of a seasonally dry tropical forest. Flora-Morphology, Distribution, Functional Ecology of Plants, 210, 40-46. https://doi.org/10.1016/j.flora.2014.10.005

Nei, M. (1973). Analysis of gene diversity in subdivided population. Proc Natl Acad Sci USA, 70(12), 3321-3. https://doi.org/10.1073/pnas.70.12.3321

Nei, M. (1978). Estimation of average heterozygosity and genetic distance from a small number of individuals. Genetics, 89, 583-1590.

Pinto, K. M. S., Melo, P. A. F. R., Nascimento, L. C., Cortez, M. I. G. M., Aires, A. A. C., Mondego, J. M., ... Lemos, R. N. S. (2018). Biological potential of extracts of Caatinga plants in the control of Alternaria alternata f. sp. citri in citrus. Journal of Agricultural Science, 10(12), 116. https://doi.org/10.5539/ jas.v10n12p116

Queiroz, L. P. (2009). Leguminosas da Caatinga. Universidade Estadual de Feira de Santana/Royal Botanic Gardens, Kew/Associação Plantas do Nordeste, Feira de Santana.

Rajora, O. M., \& Mosseler, A. (2001). Challenges and opportunities for conservation of forest genetic resources. Euphytica, 118, 197-212. https://doi.org/10.1023/A:1004150525384

Reddy, M. P., Sarla, N., \& Siddiq, E. A. (2002). Inter simple sequence repeat (ISSR) polymorphism and its application in plant breeding. Euphytica, 128, 9-17. https://doi.org/10.1023/A:1020691618797

Riegelhaupt, E. M., \& Pareyn, F. G. C. (2010). A questão energética e o manejo florestal da Caatinga. In M. A. Gariglio, E. V. S. B. Sampaio, L. A Cestaro, \& P. Y. Kageyama (Eds.), Uso sustentável e conservação dos recursos florestais da Caatinga (pp. 65-75). Serviço Florestal Brasileiro, Brasília.

Salameen, F. A., Habibi, N., Kumar, V., Amad, S. A., Dashti, J., Talebi, L., \& Bashayer, A. D. (2018). Genetic diversity and population structure of Haloxylon salicornicum moq. in Kuwait by ISSR markers. PLoS ONE, 13(11), e0207369. https://doi.org/10.1371/journal.pone.0207369

Santos, M. O., Almeida, B. V., Ribeiro, D. A., Macêdo, D. G., Macêdo, M. J. F., ... Souza, M. M. A. (2017). The conservation of native priority medicinal plants in a Caatinga area in Ceará, northeastern Brazil. Annals of the Brazilian Academy of Sciences, 89, 2675-2685. https://doi.org/10.1590/0001-3765201720160633

Sebbenn, A. M., Kageyama, P. Y., Siqueira, A. C. M. F., \& Zanatto, A. C. S. (2000). Sistemas de cruzamento em populações naturais de Cariniana legalis Mart. O. ktze.: Implicações para a conservação e o melhoramento genético. Sci For, 58, 25-40.

Sheng, Y., Zheng, W. H., Pei, K. Q., \& Ma, K. P. (2004). Population Genetic Structure of a Dominant Desert Tree, Haloxylon ammodendron (Chenopodiaceae), in the Southeast Gurbantunggut Desert Detected by RAPD and ISSR Markers. Acta Bot Sin, 46, 675-681.

Shrestha, M. K., Golan-Goldhirsh, A., \& Ward, D. (2002). Population genetic structure and the conservation of isolated population of Acacia raddiana in the Negev Desert. Biol Conserv, 108(1), 119-127. https://doi.org/10.1016/S0006-3207(02)001003

Silva, A. S., Fernandes, N. S., Cavalcante, A. M., Lima, A. O. N., \& Freitas, B. M. (2015). Florescimento induzido da jurema preta para fornecer pólen à abelha melífera na estiagem da Caatinga. Rev Caatinga, 28, 197-206. https://doi.org/10.1590/1983-21252015v28n302rc

Silva, L. A., Guimarães, E., Rossi, M. N., \& Maimoni-Rodella, R. D. C. S. (2011). Biologia da reprodução de Mimosa bimucronata: Uma espécie ruderal. Planta Daninha, 29(SP), 1011-1021. https://doi.org/10.1590/ S0100-83582011000500007

Simon, M. F., Grether, R., Queiroz, L. P., Sarkinen, T. E., Dutra, V. F., \& Hughes, C. E. (2011). The evolutionary history of Mimosa (Leguminosae): Toward a phylogeny of the sensitive plants. Am J Bot, 98(7), 1201-21. https://doi.org/10.3732/ajb.1000520 
Slatkin, S. M., \& Barton, N. H. (1989). A comparison of three indirect methods for estimating average levels of gene flow. Evolution, 43(7), 1349-1368. https://doi.org/10.1111/j.1558-5646.1989.tb02587.x

Souza, R. S. O., Albuquerque, U. P., Monteiro, J. M., \& Amorim, E. L. C. (2008). Jurema-Preta (Mimosa tenuiflora [Willd.] Poir.): A review of its traditional use, phytochemistry and pharmacology. Braz. Arch. Biol. Technol., 51(5), 937-947. https://doi.org/10.1590/S1516-89132008000500010

Wang, X., Yang, R., Feng, S., Hou, X., Zhang, Y., Li, Y., \& Ren, Y. (2012). Genetic Variation in Rheum palmatum and Rheum tanguticum (Polygonaceae), Two Medicinally and Endemic Species in China Using ISSR Markers. PloS ONE, 7(12), e51667. https://doi.org/10.1371/journal.pone.0051667

Wright, S. (1943). Isolation by distance. Genetics, 28, 114-138.

\section{Appendix A}

\section{Graphs identifying the optimal number of populations following Evanno's methods}
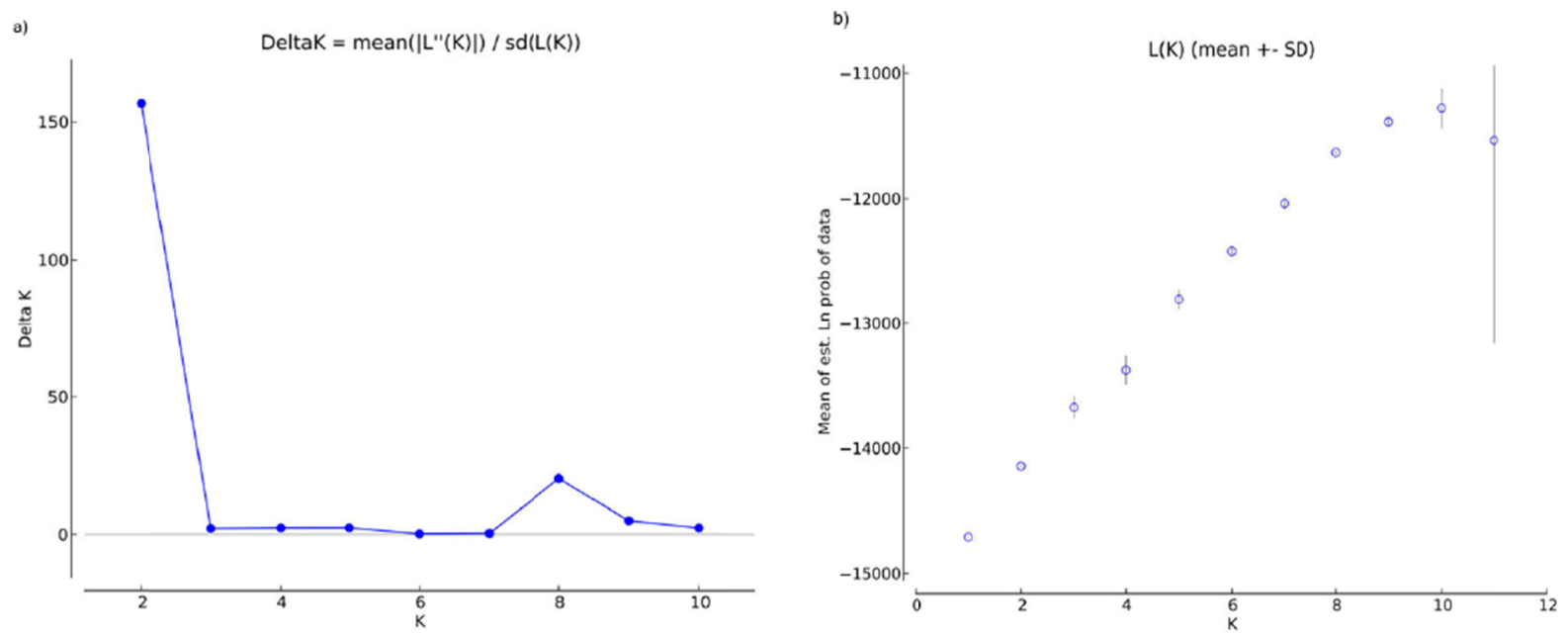

Figura A1. Graph used to demonstrate the DeltaK value (a) and the $\mathrm{L}(\mathrm{K})$ value (b), a single $\mathrm{K}$ value out of a range of $\mathrm{K}$ values, which captures the uppermost level of structure (Evanno et al., 2015)

\section{Copyrights}

Copyright for this article is retained by the author(s), with first publication rights granted to the journal.

This is an open-access article distributed under the terms and conditions of the Creative Commons Attribution license (http://creativecommons.org/licenses/by/4.0/). 